\title{
Peningkatan Kinerja Guru Melalui Supervisi Edukatif Kolaboratif Secara Periodik Di SDN Lamongrejo 4 Ngimbang Lamongan
}

\author{
Zainal Aqib \\ Sekolah Tinggi Ilmu Tarbiyah Muhammadiyah Paciran, Indonesia \\ Email: zainalaqib@yahoo.com
}

\begin{abstract}
The aim of this study wanted to describe the steps educative collaborative supervision periodically in preparing lesson plans, implement lessons, assessing student achievement, conduct follow-up assessments student achievement that can improve the performance of teachers. This performance improvement through collaborative educative periodic supervision. This research was conducted on teachers SDN Lamongrejo 4 Ngimbang Lamongan totaling 10 people. The design of the study is that the plot action research design: make a action plain, implementing the action, and reflection activities. The reflection is used as a guide for decision-making to continue or discontinue the study. Research conducted in the spiral cycles to the second cycle. The research data in the form of records of observations, field notes, documentation planning and supervision results. The main data collection instrument was a researcher, while the supporting instruments is the observation, documentation. Data were analyzed by qualitative and quantitative techniques. Based on the results of the action research can be concluded that the improved performance of teachers in preparing lesson plans, implement lessons, assessing student achievement, conduct follow-up assessments of student learning achievement. To that end, the researchers suggested that educative supervision in schools implement collaborative educative periodic supervision.
\end{abstract}

Keywords: performance, supervision, education 
Seorang guru harus selalu meningkatkan kemampuan profesionalnya, pengetahuan, sikap dan keterampilannya secara terusmenerus sesuai perkembangan ilmu pengetahuan dan teknologi termasuk paradigma baru pendidikan yang menerapkan Manajemen Berbasis Sekolah (MBS) dan Kurikulum Berbasis Kompetensi (KBK). Menurut Dirjen Pendidikan Dasar dan Menengah Departemen Pendidikan Nasional (2004, p.2) seorang guru harus memenuhi tiga standar kompetensi, di antaranya: (1) kompetensi pengelolaan pembelajaran dan wawasan kependidikan, (2) kompetensi akademik/vokasional sesuai materi pembelajaran, (3) pengembangan profesi. Ketiga kompetensi tersebut bertujuan agar guru bermutu, menjadikan pembelajaran bermutu juga, yang pada akhirnya meningkatkan mutu pendidikan Indonesia.

Untuk mencapai tiga kompetensi tersebut, sekolah harus melaksanakan pembinaan terhadap guru baik melalui workshop, PKG, diskusi dan supervisi edukatif. Hal itu harus dilakukan secara periodik agar kinerja dan wawasan guru bertambah sebab berdasarkan diskusi yang dilakukan guru di SD Negeri Lamongrejo 4, rendahnya kinerja dan wawasan guru diakibatkan (1) rendahnya kesadaran guru untuk belajar, (2) kurangnya kesempatan guru mengikuti pelatihan, baik secara regional maupun nasional, (3) kurang efektifnya PKG, dan (4) supervisi pendidikan yang bertujuan memperbaiki proses pembelajaran cenderung menitikberatkan pada aspek administrasi.
Untuk memperbaiki kinerja dan wawasan guru dalam pembelajaran di SD Negeri Lamongrejo 4, sekolah melaksanakan penelitian tindakan yang berkaitan dengan permasalahan di atas. Karena keterbatasan, maka penelitian ini hanya difokuskan pada supervisi edukatif sehingga judul adalah "Peningkatan Kinerja Guru dalam Pembelajaran di Kelas Melalui Supervisi Edukatif Kolaboratif secara Periodik".

Berdasarkan latar belakang masalah di atas, maka rumusan masalah secara umum dalam penelitian adalah: Apakah dengan supervisi edukatif kolaboratif secara periodik, kinerja guru dalam pembelajaran di kelas dapat ditingkatkan?

Adapun secara khusus, rumusan masalah penelitian ini sebagai berikut.

(1) Apakah dengan supervisi edukatif kolaboratif secara periodik dapat meningkatkan kinerja guru dalam menyusun rencana pembelajaran? (2) Apakah dengan supervisi edukatif kolaboratif secara periodik dapat meningkatkan kinerja guru dalam melaksanakan pembelajaran?

Apakah dengan supervisi edukatif kolaboratif secara periodik dapat meningkatkan guru dalam menilai prestasi belajar siswa? (4) Apakah dengan supervisi edukatif kolaboratif secara periodik dapat meningkatkan guru dalam melaksanakan tindak lanjut hasil penilaian prestasi belajar siswa?

Karena supervisi edukatif melibatkan supervisor, guru, siswa dan lingkungan maka dalam penelitian ini dilaksanakan bersama semua guru SD Negeri Lamongrejo 4 Kecamatan Ngimbang mengidentifikasi masalah 
pembelajaran.

Selanjutnya, menentukan langkah-langkah pemecahan masalah. Hasil diskusi diperoleh langkah-langkah pemecahan, yakni (1) mengadakan workshop singkat tentang pembuatan persiapan pembelajaran, pelaksanaan, dan penilaian pembelajaran di sekolah, melaksanakan supervisi edukatif kolaboratif secara periodik dengan menekankan pada pemberian bantuan untuk perbaikan pembelajaran.

Tujuan penelitian ini adalah (1) mendeskripsikan langkahlangkah supervisi edukatif kolaboratif secara periodik dalam melaksanakan pembelajaran, (2) mendeskripsikan langkah-langkah supervisi edukatif kolaboratif secara periodik dalam menilai prestasi belajar , (3) mendeskripsikan langkah-langkah supervisi edukatif kolaboratif secara periodik dalam melaksanakan tindak lanjut penilaian prestasi belajar siswa, dan (4) mendeskripsikan langkah-langkah supervisi edukatif kolaboratif secara periodik dalam menyusun rencana pembelajaran. Adapun manfaat penelitian ini adalah (1) manfaat bagi siswa: mengembangkan potensi yang dimiliki peserta didik sehingga dapat meningkatkan hasil belajarnya, (2) manfaat bagi guru: meningkatkan wawasan guru sehingga termotivasi untuk meningkatkan kinerjanya, dan (3) manfaat bagi sekolah: Menciptakan pembelajaran yang aktif, efektif, kreatif dan menyenangkan sehingga berdampak pada peningkatan mutu pendidikan.

\section{KAJIAN TEORI}

\begin{tabular}{rrr}
\multicolumn{2}{r}{ Kompetensi } & merupakan \\
spesifikasi & dari & kemampuan,
\end{tabular}

keterampilan dan sikap yang dimiliki seseorang serta penerapannya di dalam pekerjaan, sesuai dengan standar kinerja yang dibutuhkan oleh lapangan (Dirjen Dikdasmen, 2004, p.4). Berdasarkan pendapat tersebut seorang yang bekerja sebagai guru, yang pekerjaan itu menurut Undang-Undang Nomor 14 Tahun 2005 tentang Guru dan Dosen adalah pekerjaan profesional maka guru harus memenuhi standarstandar minimal yang dibutuhkan oleh Depdiknas.

Komponen-komponen stantar kompetensi guru antara lain: (1) komponen kompetensi pengelolaan pembelajaran dan wawasan kependidikan, (2) komponen kompetensi akademik/vokasional sesuai materi pembelajaran, (3) pengembangan profesi. Selain ketiga komponen tersebut, seorang guru harus memiliki sikap dan keperibadian yang positif, di mana sikap dan kepribadian tersebut senantiasa melekat pada setiap komponen yang menunjang profesi guru.

\section{Kinerja Guru}

Keberhasilan sekolah sangat bergantung pada keberhasilan kepala sekolah. Sekolah yang dikepalai oleh orang yang mempunyai komitmen tinggi terhadap peningkatan mutu maka sekolah tersebut akan cepat berkembang karena kunci keberhasilan sekolah sangat bergantung pada kepalanya. Menurut Pidarta (1980) dalam Pelangi (2005, p.23) kepala sekolah merupakan kunci kesuksesan sekolah dalam mengadakan perubahan, sehingga kegiatan meningkatkan dan memperbaiki program dan proses pembelajaran di sekolah sebagian besar terletak pada diri 
kepala sekolah itu sendiri. Lebih lanjut Pidarta (1980) menyatakan bahwa kepala sekolah memiliki peran dan tanggung jawab sebagai manajer pendidikan, pemimpin pendidikan, supervisor pendidikan, dan administrator pendidikan.

Dalam hal kinerja, kepala sekolah harus melaksanakan tugas utamanya sebagai kepala sekolah dengan penuh tanggung jawab. Menurut format penilaian kinerja sekolah Kabupaten Lamongan (2004, p.1-43) kepala sekolah harus melaksanakan tugasnya yang berkaitan dengan kepala sekolah sebagai pendidik (edukator), kepala sekolah sebagai manajer, kepala sekolah sebagai administrator, kepala sekolah sebagai penyelia (supervisor), kepala sekolah sebagai pemimpin (Leader), kepala sekolah sebagai enterprenaur (kewirausahaan).

\section{Supervisi Edukatif}

Supervisi merupakan salah satu tugas kepala sekolah yang bertujuan untuk membantu memperbaiki dan meningkatkan pengelolaan dari aspek yang disupervisi dan orang yang melakukan supervisi. Aspek yang disupervisi bisa berupa administrasi, dan edukatif, sedangkan orang yang melakukan supervisi adalah pengawas, kepala sekolah, instruktur mata pelajaran. Adapun orang yang disupervisi bisa kepala sekolah, guru mata pelajaran, guru pembimbing, tenaga edukatif yang lain, tenaga administrasi, dan siswa.

Supervisi edukatif merupakan supervisi yang diarahkan pada kurikulum pembelajaran, proses belajar mengajar, pelaksanaan bimbingan dan konseling. Supervisi ini dapat dilakukan oleh pengawas, kepala sekolah, maupun guru senior yang sudah pernah menjadi instruktur mata pelajaran. Menurut Dirjen Dikmenum (1984:15) pelaksanaan supervisi tersebut dapat dilakukan dengan cara wawancara dan observasi.

\section{Hipotesis Tindakan}

Hipotesis tindakan dalam penelitian ini adalah "Kinerja guru dalam pembelajaran di kelas akan meningkat jika supervisi edukatif dilaksanakan dengan sistematis dan proaktif."

\section{Metode Penelitian}

Penelitian ini dilaksanakan di SD Negeri Lamongrejo 4 Kecamatan Ngimbang Kabupaten Lamongan. Penelitian ini diilhami oleh penelitian-penelitian guru yang telah mengikuti seleksi kepala sekolah. Pada tahun itu banyak hasil penelitian yang kurang mengarah pada peningkatan mutu pendidikan.

Peneliti mengambil tempat penelitian di SD Negeri Lamongrejo 4 Kecamatan Ngimbang karena SD itu memiliki beragam guru. Guru-guru di SD tersebut ada yang guru tidak tetap, guru bantu, guru pegawai negeri sipil, dan ijazahnya pun beragam, yakni ada yang berijazah diploma, sarjana, dan pascasarjana.

Selama penelitian tersebut peneliti mengumpulkan data awal, menyusun program supervisi, pelaksanaan supervisi, analisis, dan tindak lanjut.

Untuk menjawab permasalahan, ada beberapa faktor yang diselidiki sebagai berikut, (1) guru, melihat peningkatan kemampuan guru dalam membuat rencana pembelajaran, melaksanakan pembelajaran, menilai prestasi 
belajar, dan melaksanakan tindak lanjut hasil penilaian prestasi belajar siswa sebelum penelitian dan dalam penelitian tindakan,

pembelajaran, memperhatikan keefektifan pembelajaran di kelas yang dikelola oleh guru dengan menerapkan strategi pembelajaran yang sesuai dengan materi pembelajaran, (3) siswa, memperhatikan motivasi belajar siswa dan hasil belajar, yang dilihat juga hasil nilai ujian akhir nasional, khusus mata pelajaran bahasa Indonesia, bahasa Inggris dan matematika, (4) supervisor, memperhatikan tindakan supervisor selama melakukan supervisi edukatif Karena penelitian ini merupakan penelitian tindakan maka pelaksanaan ini dilaksanakan secara siklus. Pelaksanaannya selama dua siklus. Siklus-siklus itu merupakan rangkaian yang saling berkelanjutan, maksudnya siklus kedua merupakan kelanjutan dari siklus pertama. Setiap siklusnya selalu ada persiapan tindakan, pelaksanaan tindakan, pemantauan, evaluasi, dan refleksi.

Teknik pengumpulan data pada penelitian ini terdiri atas empat kegiatan pokok yakni pengumpulan data awal, data hasil analisis setiap akhir siklus, serta tanggapan lain dari guru terhadap pelaksanaan supervisi edukatif model kolaboratif.

Data yang telah dikumpulkan dianalisis dengan menggunakan analisis kualitatif dan kuantitatif. Analisis kualitatif digunakan untuk menjelaskan perubahan perilaku guru dalam pembelajaran dan perilaku supervisor dalam melaksanakan supervisi guru. Adapun analisis kuantitatif digunakan untuk mengetahui keberhasilan guru dan siswa berdasarkan standar kompetensi guru yang telah ditetapkan oleh Depdiknas sebagai berikut.

a. Nilai $81-80=$ amat baik (A) berhasil

b. Nilai $76-80=$ baik (B) berhasil

c. Nilai $55-75=\operatorname{cukup}(\mathrm{C})$ belum berhasil

d. Nilai $0-54=$ kurang (D) belum berhasil

Keseluruhan data yang terkumpul selanjutkan dipergunakan untuk menilai keberhasilan tindakan yang diberikan dengan indikator keberhasilan sebagai berikut. (1) Terjadi peningkatan kinerja guru dalam menyusun rencana pembelajaran, (2) terjadinya peningkatan kinerja guru dalam melaksanakan pembelajaran, (3) terjadinya peningkatan kinerja guru dalam menilai prestasi belajar siswa, (4) terjadinya peningkatan kinerja guru dalam melaksanakan tindak lanjut hasil penilaian prestasi belajar siswa, dan (5) terjadinya pembelajaran efektif yang mampu memotivasi belajar siswa dengan meningkatnya hasil belajar terutama nilai ujian akhir Sekolah .

\section{Hasil Penelitian Dan Pembahasan}

Temuan pertama, kinerja guru meningkat dalam membuat perencanaan pembelajaran. Hal ini terjadi karena adanya kerja sama antara guru mata pelajaran yang satu dengan lainnya dengan dibantu oleh guru senior yang ditugasi oleh kepala sekolah untuk mensupervisi guru tersebut. Langkah-langkah yang dapat meningkatkan kinerja guru dalam membuat persiapan pembelajaran ada lima. Pertama, guru senior/supervisor memberikan format supervisi dan jadwal supervisi pada awal tahun pelajaran atau awal 
semester. Pelaksanaan supervisi tidak hanya dilakukan sekali. Kedua, guru senior selalu menanyakan perkembangan pembuatan perangkat pembelajaran (mengingatkan betapa pentingnya perangkat pembelajaran). Ketiga, satu minggu sebelum pelaksanaan supervisi perangkat pembelajaran, supervisor/guru senior menanyakan format penilaian, jika format yang diberikan pada awal tahun pelajaran tersebut hilang, maka guru yang bersangkutan disuruh memfotokopi arsip sekolah. Jika di sekolah masih banyak format seperti itu maka guru tersebut diberi kembali. Bersamaan dengan memberi/menanyakan format, supervisor meminta pengumpulan perangkat pembelajaran yang sudah dibuatnya untuk untuk diteliti kelebihan dan kekurangannya. Keempat, supervisor memberikan catatan-catatan khusus pada lembaran untuk diberikan kepada guru yang akan disupervisi. Kelima, supervisor dalam menilai perangkat pembelajaran penuh perhatian dan tidak mencerminkan sebagai penilai. Supervisor bertindak sebagai kolaborasi. Supervisor membimbing, mengarahkan guru yang belum paham, tetapi supervisor juga menerima argumen guru yang positif. Dengan adanya itu, terciptalah hubungan yang akrab antara guru dan supervisor. Tentu saja ini akan membawa nilai positif dalam pelaksanaan pembelajaran.

Temuan kedua, kinerja guru meningkat dalam melaksanakan pembelajaran. Dalam penelitian tindakan ini ternyata dari sepuluh guru hampir semuanya mampu melaksanakan pembelajaran dengan baik. Hal ini terbukti dari hasil supervisi. Langkah-langkah yang dilakukan untuk meningkatkan pelaksanaan pembelajaran berdasarkan penelitian tindakan ini adalah: (1) Supervisor yang mengamati guru mengajar tidak sebagai penilai tetapi sebagai rekan bekerja yang siap membantu guru tersebut, (2) Selama pelaksaaan supervisi di di kelas guru tidak menganggap supervisor sebagai penilai karena sebelum pelaksanaan supervisi guru dan supervisor telah berdiskusi permasalahanpermasalahan yang ada dalam pembelajaran tersebut, (3) Supervisor mencatat semua peristiwa yang terjadi di dalam pembelajaran baik yang positif maupun yang negatif, (4) Supervisor selalu memberi contoh pembelajaran yang berorientasi pada Modern Learning. (5) Jika ada guru yang pembelajarannya kurang jelas baik tujuan, penyajian, maupun umpan balik maka supervisor memberikan contoh bagaimana menjelaskan tujuan, menyajikan, memberi umpan balik kepada guru tersebut, (6) Setelah guru diberi contoh pembelajaran modern, supervisor setiap dua atau tiga minggu mengunjungi atau mengikuti guru tersebut dalam proses pembelajaran.

Temuan ketiga, kinerja guru meningkat dalam menilai prestasi belajar siswa. Pada penelitian tindakan yang dilakukan di SD Negeri Lamongrejo 4 Kecamatan Ngimbang ini ternyata pelaksanaan supervisi edukatif kolaboratif secara periodik memberikan dampak positif terhadap guru dalam menyusun soal/perangkat penilaian, melaksanakan, memeriksa, menilai, mengolah, menganalisis, menyimpulkan, menyusun laporan dan memperbaiki soal. Sebelum diadakan supervisi edukatif secara kolaboratif, guru banyak yang 
mengalami kesulitan dalam melaksanakan penilaian. Langkahlangkah yang dilakukan dalam supervisi edukatif kolaboratif secara periodik yang dapat meningkatkan kinerja guru adalah: (1) Supervisor berdiskusi dengan guru dalam pembuatan perangkat penilaian sebelum dilaksanakan supervisi, (2) Guru melaksanakan penilaian sesuai dengan aturan yang telah ditetapkan bersama supervisor yang sebagai kolaboratif dalam pembelajaran, (3) Guru membuat kriteria penilaian yang berkaitan dengan penskoran, pembobotan, dan pengolahan nilai, yang sebelum pelaksanaan supervisi didiskusikan dengan supervosor,dan (4) Guru menganalisis hasil penilaian dan melaporkannya kepada urusan kurikulum.

Temuan keempat, kinerja guru meningkat dalam melaksanakan tindak lanjut hasil penilaian prestasi belajar peserta didik. Langkah-langkah yang dapat meningkatkan kinerja guru dalam supervisi edukatif kolaboratif adalah: (1) Supervisor dan guru bersamasama membuat program tindak lanjut hasil penilaian, (2) Guru senior/supervisor memberi contoh pelaksanaan tindak lanjut, yang akhirnya dilanjutkan oleh guru dalam pelaksanaan yang sebenarnya, dan (3) Supervisor atau guru senior mengajak diskusi pada guru yang telah membuat, melaksanakan, dan menganalisis program tindak lanjut.

Temuan kelima, kinerja guru meningkat dalam menyusun program pembelajaran, melaksanakan pembelajaran, menilai prestasi belajar, dan melaksanakan tindak lanjut hasil prestasi belajar siswa ternyata membawa kenaikan prestasi siswa dalam mengikuti Ujian Akhir Sekolah.

\section{Kesimpulan Dan Saran Kesimpulan}

Berdasarkan temuan hasil penelitian ada empat hal yang dikemukakan dalam penelitian tindakan ini, yakni simpulan tentang: (1) Peningkatan kinerja guru dalam menyusun rencana pembelajaran, (2) Peningkatan kinerja guru dalam melaksanakan pembelajaran, (3) Peningkatan kinerja guru dalam menilai prestasi belajar, (4) Peningkatan kinerja guru dalam melaksanakan tindak lanjut hasil penilaian prestasi belajar siswa.

Ada beberapa saran yang perlu disampaikan kepada pengambil kebijakan sekolah, di antaranya adalah: (1) supervisi terhadap semua guru perlu dilakukan secara periodik dan ditetapkan pada awal tahun pelajaran (pada saat pembagian tugas), (2) supervisi edukatif ternyata membawa peningkatan kinerja guru dan hasil belajar siswa jika dilaksanakan secara kolaboratif, (3) supervisi edukatif kolaboratif akan bermakna jika supervisornya adalah teman sejawat yang sudah mampu pada mata pelajaran yang bersangkutan, (4) kepala sekolah perlu memberi kesempatan pada guru-guru yang dianggap sudah mampu mensupervisi guru lain.

\section{Saran}

Diharapkan untuk penulis yang akan datang dapat melengkapi kekurangan penulis pada penelitian ini. karena sesungguhnya penelitian ini jauh dari kata sempurna. Dan diharapkan penelitian yang akan datang dapat mendapatkan hasil dari Kinerja Guru Melalui Supervisi Edukatif Kolaboratif yang lebih sempurna 


\section{Daftar Rujukan}

Depdiknas.2005. Peraturan pemerintah Nomor 19 Tahun 2005 tentang Standar Nasional Pendidikan, Jakarta .2003. Undang-Undang Republik Indonesia Nomor 20 tahun 2003

tentang Sistim Pendidikan

Nasional; Jakarta

.2004. Standar Kompetensi Guru Sekolah Dasar .Jakarta: Depdiknas

.2004. Kurikulum 2004 Pedoman Pemilihan Bahan dan Pemanfaatan bahan Ajar. Jakarta. Depdiknas.

.2004. kurikulm 2004 Pedoman Supervisi Pengajaran Sekolah Dasar. Jakarta: Depdiknas

.2004. Petunjuk Pelaksanaan Supervisi Pendidikan di Sekolah Jakarta: Depdiknas .2003. Penuntasan Wajib Belajar Pendidikan Dasar Sembilan Tahun. Jakarta: Depdiknas.

.2001. Manajemen Berbasis Sekolah .Jakarta: Depdiknas.

Mulyasa, E. 2003. Manajemen Berbasis Sekolah. Konsep, Strategi dan Implementasi, Bandung: Rosda Karya.

Pidarta, I Made.1980. Perencana Pendidikan Dengan Pendekatan Sistem. Jakarta: Rineke Cipta.

Purwanto,

Ngalim.1977..Administrasi dan Supervisi Pendidikan. Bandung. Remaja Karya.

Suharsimi Arikunto, 2006, Penelitian Tindakan Kelas, Jakarta, Bumi Aksara.

Zainal Aqib, 2006, PTK Untuk Guru. Bandung. Yrama Widya 